\title{
Effect of Stem Diameter, Genetics, and Wood Properties on Stem Cracking in Norway Spruce
}

\author{
Pauls Zeltiňs ${ }^{1, *}$, Juris Katrevičs ${ }^{1}$, Arnis Gailis ${ }^{1}$, Tiit Maaten ${ }^{2}$, Endijs Bāders ${ }^{1} \mathbb{C}$ and \\ Āris Jansons ${ }^{1}$ \\ 1 Latvian State Forest Research Institute "Silava", 111 Rigas Street, LV-2169 Salaspils, Latvia; \\ juris.katrevics@silava.lv (J.K.); arnis.gailis@silava.lv (A.G.); endijs.baders@silava.lv (E.B.); \\ aris.jansons@silava.lv (Ā.J.) \\ 2 Institute of Forestry and Rural Engineering, Estonian University of Life Sciences, \\ Kreutzwaldi 5, 51014 Tartu, Estonia; tiit.maaten@emu.ee \\ * Correspondence: pauls.zeltins@silava.lv; Tel.: +371-22-315-010
}

Received: 3 August 2018; Accepted: 4 September 2018; Published: 6 September 2018

\begin{abstract}
The choice of seed material (genetics) is one of the tools that can improve adaptation to the changing climate. Insufficient adaptation can result in a number of potential risks, including stem cracking. The goal of this study is to assess the influence of genetics and wood properties on stem cracking in Norway spruce (Picea abies Karst). The study was conducted on a 35-year-old provenance trial in Eastern Latvia. Stem cracks were assessed using a six-score scale. Tree-ring parameters, i.e., latewood proportion, maximum and mean density, mean earlywood, and latewood density were analysed. The overall incidence of stem cracking was $23.5 \%$, varying between $0 \%$ and $79 \%$ at a family mean level. Heritability of stem cracking was low, ca., two times lower than for the diameter at breast height $(\mathrm{DBH}): h^{2}=0.09$ and 0.21 , respectively. There were non-significant family and provenance effects on the occurrence of stem cracks, and weak family mean correlations between $\mathrm{DBH}$, and the proportion of trees with any stem cracks or severe stem cracks. Overall, larger trees were more prone to cracking irrespective of provenance or family. Cracked trees had lower wood density parameters than unaffected trees, yet the latewood proportion was similar. Silvicultural treatments or selection to improve wood density could be suggested to reduce the risk of stem cracking.
\end{abstract}

Keywords: stem scars; stem defects; heritability; wood density

\section{Introduction}

Norway spruce is economically important, compared to other forest trees and fast-growing tree species, and it covers extensive areas of the Baltic Sea region [1,2]. A high rate of survival and reduced risks of damage are essential to ensure the financial viability of the increasing investments in regeneration (primarily planting), especially while using genetically improved seedlots [3-5]. Therefore, not only high-volume production and timber quality, but also adaptive traits, are important breeding objectives [6,7]. The use of tree breeding results are expected to be an important tool for the adaptation of forestry to climatic changes [8]. In the region studied, the most pronounced effects of these are longer vegetation seasons and milder winters, as well as prolonged drought periods during the summer [9].

Prolonged drought periods are the probable triggering factor of stem cracks in Norway spruce. Tension inside the tracheid increases with an increasing water deficit until cell collapse occurs; when hydrostatic tension in the tracheids exceed the fracture limits of the middle lamella, and cracks occur [10-12]. The cracks are usually longitudinal, up to several meters long, and radially reach into the stem [10]. Sometimes cracks can be closed and appear as scars, with stained black coverage [13]. 
These obviously decrease timber quality, and trees with such open wounds in the stem are more prone to fungal infections [14-16].

Cracks may be a symptom of insufficient adaptation [10], and they have been observed in sample plots in the National Forest Inventory, also in Latvia [17]. Yet, there is a lack of detailed analysis linking the occurrence of cracks with wood properties. In recent decades, stem cracking in Norway spruce has been reported in Fennoscandia, especially on 15-35 year old plantations on former agricultural land, and originating from transferred reproductive material $[10,13,18,19]$. Also, in Latvia, geographically distant provenances demonstrated a significantly different frequency of trees with cracks [20]. However, there remains a lack of information on family-level genetic variations and the heritability of stem cracks needed for consideration in tree breeding. In addition, only one study has reported information on this important stem defect in the Baltic States [20]. It is important to both raise awareness of this potentially increasing problem, as well as improve the understanding of it in the context of potential adaptation measures. Therefore, the goal of the study is to assess the influence of genetics and wood properties on stem cracking in Norway spruce.

\section{Materials and Methods}

\subsection{Studied Trial and Measurements}

The assessed Norway spruce provenance trial was located in the eastern part of Latvia $\left(56^{\circ} 39^{\prime} \mathrm{N}\right.$, $25^{\circ} 54^{\prime} \mathrm{E}$ ), established in 1985 on former agricultural land with four-year-old bare-rooted plants with an initial density of 3333 stems ha $^{-1}(2 \times 1.5 \mathrm{~m})$. The mean annual temperature in the location was $+6.0^{\circ} \mathrm{C}$; the mean monthly temperature ranged from $-6.4{ }^{\circ} \mathrm{C}$ in February to $+17.1{ }^{\circ} \mathrm{C}$ in July. The mean annual precipitation was ca. $700 \mathrm{~mm}$ [21]. The trial consisted of six local provenances (the locations of the sources from which the reproductive material was collected) from the southeast area of Latvia, with a known family structure (Table 1). A randomized complete block design was used with five blocks and 10 trees per plot. In 1995, systematic thinning had been done, retaining approximately 1600 stems ha $^{-1}$.

The diameter at breast height (DBH) was measured on each living tree in the summer of 2016. Height was impossible to measure due to a very high stand density. Stem cracks were assessed using a six-score scale according to methodology by Zeltinš et al. [20]. Score 0 was assigned to trees without visible cracks or scars. Score 1 was assigned to trees with bark cracks that were a few centimetres long and shallow, not reaching the wood. Score 2 characterized a shallow crack in the bark up to ca. $1 \mathrm{~m}$. Moderate damage (Score 3) was a crack in the bark and reached the wood, or closed scars from 1 to $2 \mathrm{~m}$ long with stained black coverage. Severe damage (Score 4) was a deep crack in the wood and scars with stained black coverage longer than $2 \mathrm{~m}$. Very severe damage (Score 5) was assigned to trees with one or more open stem cracks that were several meters long, which reached radially deep into the stem [20].

In autumn, 2016, $5 \mathrm{~mm}$ increment cores at breast height were randomly collected from 17 trees with severe to very severe damage (Scores 4 or 5), and 17 controlled undamaged trees (Score 0 ). Only straight trees without visible crown asymmetry and other stem defects like root-rot, double tops, severe browsing damage, etc., were chosen. The increment cores were processed using high-frequency densitometry with the LignoStation wood analysis system, which utilizes the dielectric properties of wood [22]. For each sample core, ring width, latewood width, mean, earlywood, latewood, and maximum density were measured, and the proportion of latewood (latewood width/tree-ring width) was calculated and further used as an integrative parameter for both ring and latewood widths. 
Table 1. Overview of the material used in the trial (SD—standard deviation).

\begin{tabular}{|c|c|c|c|c|c|c|c|c|c|c|c|}
\hline \multirow{2}{*}{ Provenance } & \multirow{2}{*}{ Geographic Coordinates } & \multirow{2}{*}{ No of Families } & \multicolumn{6}{|c|}{ No of Trees with Cracking Score } & \multicolumn{2}{|c|}{ Mean Diameter at Breast Height \pm SD (cm) } & \multirow{2}{*}{ Incidence of Stem Cracks (\%) } \\
\hline & & & 0 & 1 & 2 & 3 & 4 & 5 & without Stem Cracks & with Stem Cracks & \\
\hline Bērzgale & $56^{\circ} 36^{\prime} \mathrm{N}, 27^{\circ} 30^{\prime} \mathrm{E}$ & 26 & 210 & 20 & 12 & 13 & 12 & 7 & $18.2 \pm 4.63$ & $19.8 \pm 5.66$ & 23.4 \\
\hline Dagda & $56^{\circ} 6^{\prime} \mathrm{N}, 27^{\circ} 30^{\prime} \mathrm{E}$ & 29 & 263 & 31 & 16 & 14 & 2 & 6 & $18.1 \pm 4.08$ & $18.2 \pm 4.82$ & 20.8 \\
\hline Janopole & $56^{\circ} 23^{\prime} \mathrm{N}, 27^{\circ} 18^{\prime} \mathrm{E}$ & 26 & 178 & 16 & 19 & 12 & 8 & 14 & $18.2 \pm 4.33$ & $20.7 \pm 4.68$ & 27.9 \\
\hline Kalsnava & $55^{\circ} 42^{\prime} \mathrm{N}, 26^{\circ} 41^{\prime} \mathrm{E}$ & 24 & 227 & 17 & 18 & 10 & 8 & 12 & $17.9 \pm 4.06$ & $19.1 \pm 4.57$ & 22.3 \\
\hline Kalupe & $56^{\circ} 6^{\prime} \mathrm{N}, 26^{\circ} 30^{\prime} \mathrm{E}$ & 24 & 202 & 18 & 15 & 8 & 11 & 15 & $17.9 \pm 4.05$ & $18.8 \pm 4.60$ & 24.9 \\
\hline Silene & $56^{\circ} 42^{\prime} \mathrm{N}, 25^{\circ} 53^{\prime} \mathrm{E}$ & 23 & 202 & 22 & 10 & 10 & 5 & 13 & $18.2 \pm 4.47$ & $19.9 \pm 4.72$ & 22.9 \\
\hline Total & & 152 & 1282 & 124 & 90 & 67 & 46 & 67 & $18.1 \pm 4.27$ & $19.4 \pm 4.84$ & 23.5 \\
\hline
\end{tabular}




\subsection{Data Analysis}

Variance and covariance components for the genetic analysis were estimated using the $\mathrm{SAS}^{\circledR}$ Mixed procedure (PROC MIX) (SAS Institute, Cary, NC, USA) with a restricted maximum likelihood approach for analysing the DBH and the generalized linear mixed procedure (PROC GLIMMIX) (SAS Institute, Cary, NC, USA), applying a cumulative logit link function for analysing the stem cracking score. The following analytical model was used:

$$
y_{i j k l}=\mu+B_{i}+P_{j}+F_{k(j)}+B F_{i k(j)}+e_{i j k l}
$$

where $y_{i j k l}$ is the observation of stem cracks on the $l$ th tree from the $k$ th family within the $j$ th provenance in the $i$ th block; $\mu$ is the general mean; $B_{i}$ and $P_{j}$ are the fixed effects of the $i$ th block and the $j$ th provenance, respectively. The $F_{k(j)}$ is the random effect of the $k$ th family within the $j$ th provenance, and $B F_{i k(j)}$ is the random interaction effect of the $i$ th block, and the $k$ th family within the $j$ th provenance (plot effect). $e_{i j k l}$ is the random residual effect. The significance of the random factors was estimated with Wald $\mathrm{Z}$ tests, based on the estimates and asymptotic standard errors in the SAS output.

Estimates of narrow-sense individual tree heritability $\left(h^{2}\right)$ and family mean heritability $\left(h^{2}\right)$ were obtained for DBH and stem cracking variance components from the analytical model described above. For stem cracking, the environmental variance $\hat{\sigma}_{e}^{2}$ was fixed to be $\pi^{2} / 3=3.29$ [23]. The individual tree heritability was calculated as [24]:

$$
h^{2}=\frac{4 \times \hat{\sigma}_{f}^{2}}{\hat{\sigma}_{f}^{2}+\hat{\sigma}_{f b}^{2}+\hat{\sigma}_{e}^{2}}
$$

where $\hat{\sigma}_{f}^{2}, \hat{\sigma}_{f b}^{2}$, and $\hat{\sigma}_{e}^{2}$ are the estimated variance components of the family, family $\times$ block interaction, and the residual, respectively. The Family mean heritability was calculated using the formula [24]:

$$
h_{f}^{2}=\frac{\hat{\sigma}_{f}^{2}}{\hat{\sigma}_{f}^{2}+\frac{\hat{\sigma}_{f b}^{2}}{b}+\frac{\hat{\sigma}_{e}^{2}}{b n}}
$$

where $b$ is the number of blocks and $n$ is the number of trees per plot.

The effects of DBH and DBH $\times$ provenance interaction on the severity (score) of stem cracks were assessed by a mixed model:

$$
y_{i j k l}=\mu+D_{i j k l}+P D_{i j k l}+B_{i}+F_{k(j)}+B F_{i k(j)}+e_{i j k l}
$$

where $D_{i j k l}$ and $P D_{i j k l}$ are the fixed effects of the $\mathrm{DBH}$ of the $l$ th tree from the $k$ th family within the $j$ th seedlot in the $i$ th block, and the provenance $\times \mathrm{DBH}$ interaction. $B_{i}$ and $F_{k(j)}$ are the random effects of the block, and the $k$ th family within the $j$ th provenance, and $B F_{i k(j)}$ is the random interaction effect of the $i$ th block and the $k$ th family within the $j$ th provenance, and $e_{i j k l}$ is the random residual effect. The ordinal logistic function was applied using R package ordinal [25]. Pearson correlation analyses based on family mean observations was used to quantify the association between the DBH and the incidence of trees with stem cracks (score $>0$ ), and the incidence of trees with severe stem cracks (Score 4 and 5).

For the increment cores, the measured time series were cross-dated and verified by a graphical inspection and statistically using the program COFECHA [26], as described by [27]. The tree ring parameters between the core samples with and without cracks were compared by a $t$-test. The calculations were done in an R software environment for statistical computing [28]. 


\section{Results}

\subsection{Effect of DBH and Genetics}

The trial mean DBH \pm standard deviation (SD) was $18.4 \pm 4.44 \mathrm{~cm}$. The overall incidence of stem cracks was $23.5 \%$ (Table 1). The provenance mean incidence of stem cracks varied from ca. $22 \%$ to $28 \%$ (Table 1 ), and family mean varied from $0 \%$ to $78.6 \%$ (Figure 1 ). Long stem cracks or scars up to several meters were observed. The family mean proportion of trees with the largest cracks (Score 4 and 5), ranged from $0 \%$ to $50 \%$, and was on average $6.7 \%$. The DBH was a significant factor $(p<0.01)$, determining the incidence of stem cracks of any severity, yet the interaction effect of provenance $x$ DBH was insignificant $(p=0.08)$. Thus, within each of the provenances, faster-growing trees were more greatly affected.

Neither provenance nor family were a significant factor ( $p=0.37$ and $p=0.16$, respectively) affecting the occurrence of stem cracks, while the block had a significant impact $(p=0.01)$. However, trees with stem cracks did not tend to occur in clusters. The estimated family variance formed a small proportion of phenotypic variance, resulting in a rather low individual-tree heritability $h^{2}{ }_{i} \pm$ standard error (SE) $=$ $0.09 \pm 0.091$, as well as family mean heritability $h_{\text {fam }}^{2} \pm \mathrm{SE}=0.20 \pm 0.206$ (Table 2). Individual tree and family mean heritabilities $( \pm \mathrm{SE}$ ) for DBH were $0.21 \pm 0.088$ and $0.31 \pm 0.128$, respectively.

Based on family means (152 families), no clear tendency for a genetic relationship was observed between family mean DBH and (a) the incidence of stem cracks (Score $>0)$ within a family $(r=0.028$, $p=0.75$ ), or (b) the incidence of severe cracks (Score 4 and 5$)$ within a family $(r=0.059, p=0.50$ ) (Figure 1). Thereby, severely cracking trees were among families with a small as well as large mean DBH.

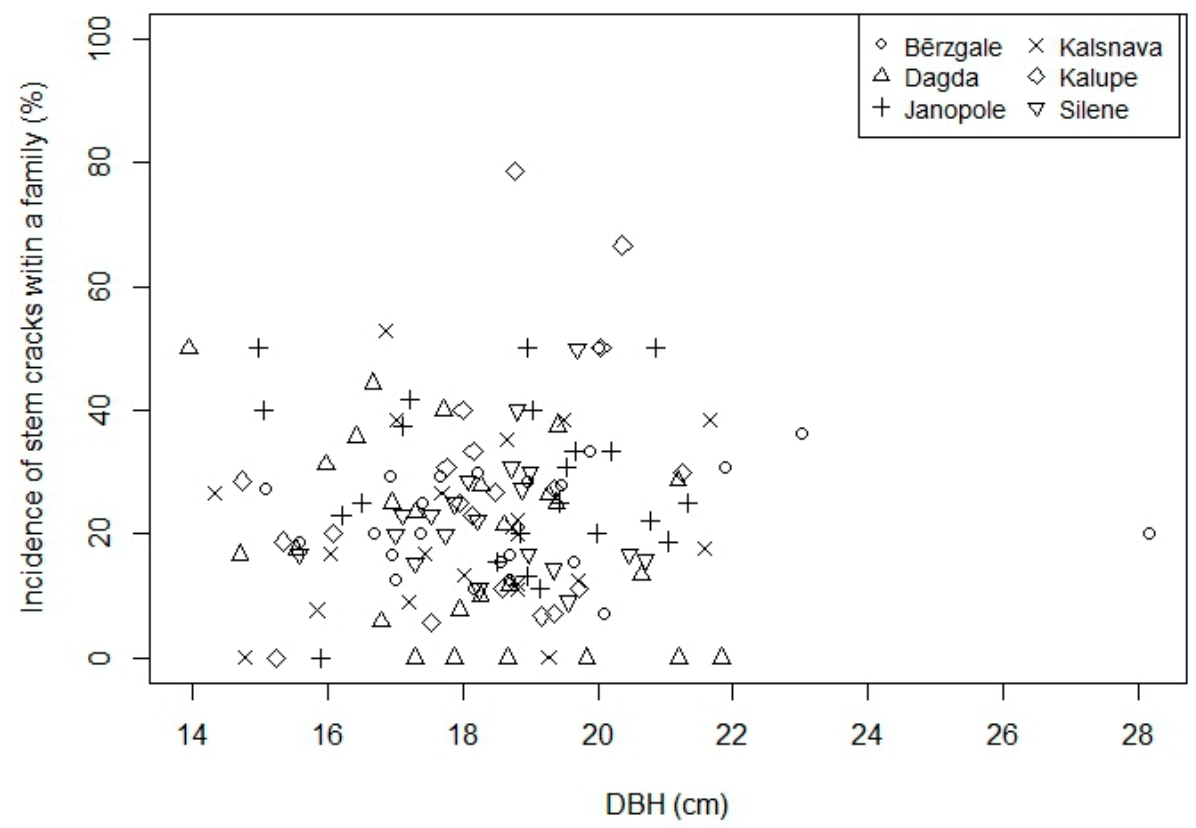

Figure 1. Differences in diameter at breast height $(\mathrm{DBH})$ and the incidence of stem cracks among families.

Table 2. Estimated variance and covariance components and heritability for stem cracking.

\begin{tabular}{lc}
\hline \multicolumn{1}{c}{ Component } & Estimate (Standard Error) \\
\hline Additive genetic (family) variance & $0.074(0.077)$ \\
Variance of additive genetic variance & 0.006 \\
Family $\times$ block variance & $0.013(0.130)$ \\
Environmental variance & 3.29 \\
Individual-tree narrow sense heritability & $0.088(0.091)$ \\
Family mean heritability & $0.198(0.206)$ \\
\hline
\end{tabular}




\subsection{Tree-Ring Analysis}

Core samples from severely cracked trees (Score 4 and 5) had a significantly lower wood density $(p<0.01)$ than unaffected trees (Table 3). For cracked trees, the maximum, mean, mean earlywood, and mean latewood densities were $8.9 \%, 17.0 \%, 17.0 \%$, and $8.4 \%$, respectively, and they were lower for unaffected trees. However, the latewood proportion did not differ $(p=0.97)$ between either group of sample trees (Table 3).

Comparing the tree-ring parameters on an annual basis showed mostly negligible differences occurred in any given year between both groups of trees (Figure 2). For the mean density, the most notable differences were during the period of 2010-2015, when cracked trees had a significantly lower mean density than the unaffected samples in the years 2013-2015 (Figure 2). Earlywood density tended to be higher for undamaged trees during all observation periods, though significant differences were estimated only within individual years.
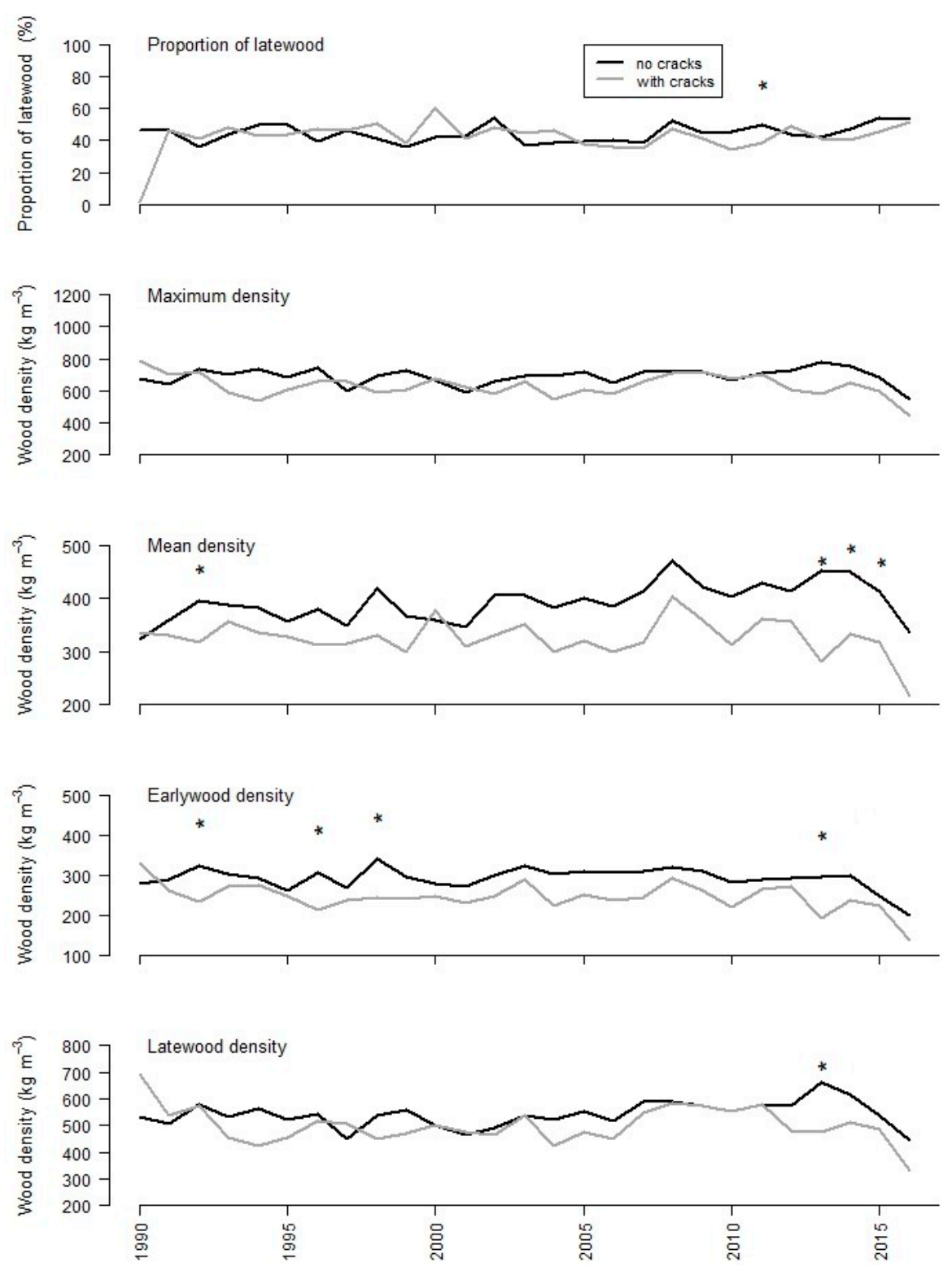

Figure 2. Mean measurement time series of four analysed Norway spruce groups $\left({ }^{*}\right.$ denote significant differences $(p \leq 0.05)$ between trees with and without cracks). 
Table 3. Statistics of tree-ring parameters ( $\mathrm{MIN}=$ minimum, $\mathrm{MAX}=$ maximum, $\mathrm{MEAN}=$ mean values, $\mathrm{SD}=$ standard deviation, $\mathrm{DIFF}=p$ values of differences in mean values of mean time series of the tree-ring parameters of the two analysed groups).

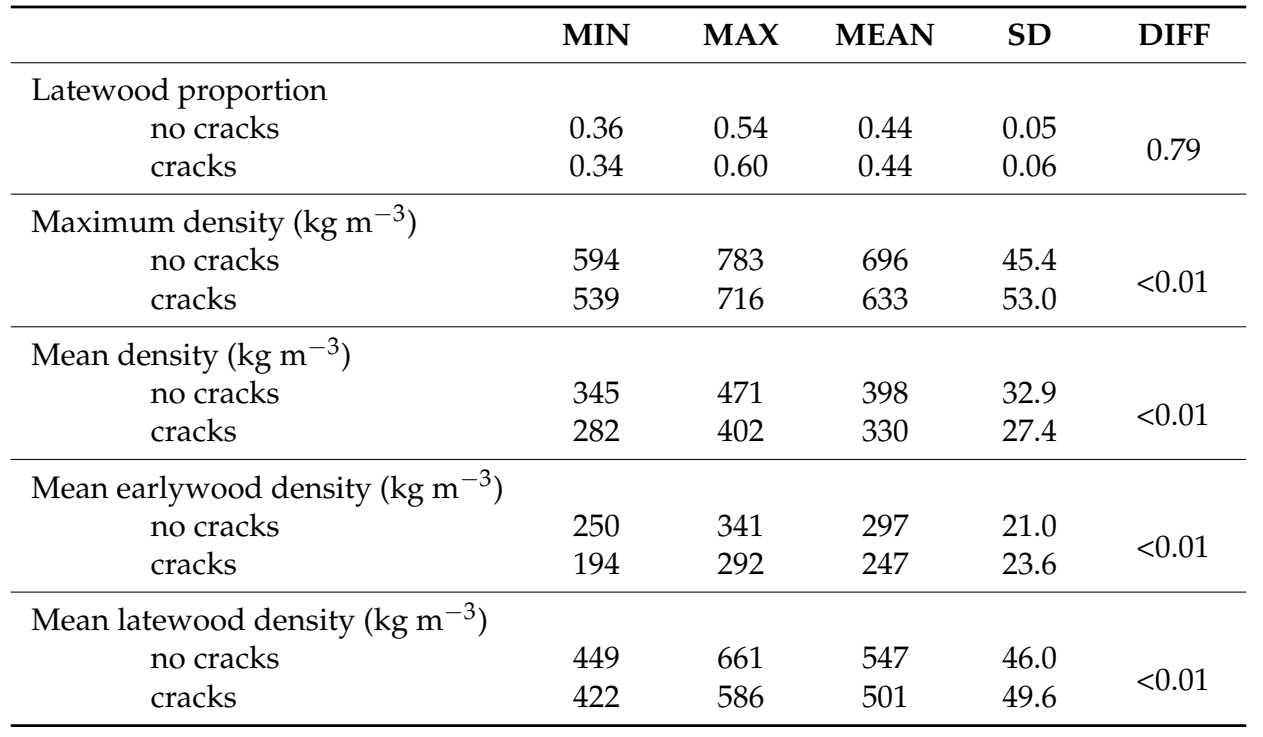

\section{Discussion}

At the study site, the frequency of cracked stems (23.5\%) was higher than was reported in earlier studies. The incidence of stem cracks in the IUFRO 1964/68 series was 7\% for Bjerkøy (Norway) and $2 \%$ for Abild (Sweden) [13]. In the Swedish combined clonal and seedling seed orchard, around $4 \%$ of the trees showed cracking [29]. In Lithuania, the frequencies of 36-year-old trees with scars and cracks in the seed orchard were $10.9 \%$ and $14.8 \%$, respectively [14]. In the 15-30-year-old provenance trials, located in Norway, the frequency of cracked stems varied from $0 \%$ to $20.3 \%$ [10]. In two 41-44-year-old contiguous provenance trials in Western Latvia, 31\% of trees with stem cracks were reported [20]. Yet, most of the damage ( $28 \%$ of all trees) was light cracks in the bark, believed not to affect wood properties primarily and considerably, contrary to the observed severely damaged (Scores 4 and 5) trees (ca. $7 \%$ ), with cracks that were several meters long at the present study site.

More frequent severe stem cracks among larger trees indicated a potential risk for Norway spruce plantations with fast radial growth, which is further supported by the results of earlier studies in the region $[10,13,14,30]$. In this study site, the forest type corresponded to the fertile Oxalidosa. Earlier studies suggest that fast growing spruce plantations on abandoned agricultural land, planted with wide spacing, are most vulnerable to cracking $[10,13,29,31]$. On rocky forest soil, cracks tend to occur less frequently [19]. However, in the studied trial, the initial spacing of $1.5 \times 2 \mathrm{~m}$ and the density was kept high until the moment of inspection, due to the lack of frequent thinning.

In spite of the dense stand, the frequency of cracked stems was relatively high, indicating the importance of other factors (fertile soil and/or extreme climatic events in the past) influencing the growth of trees and enhancing stem cracking. No positive correlation between stem dimensions and the frequency of stem cracks and/or wounds has been found in Finland, where severe cracks appeared across the whole DBH spectrum [19]. We found no evidence to confirm the conclusions [10], that trees under a certain DBH do not crack, and that "as a rule there is only one crack at a given height." At the study site, a number of trees with two or three severe cracks at the same height (Score 5) were found.

Clear tendency toward a higher frequency of stem cracks in provenances with rapid growth had been highlighted [32]. In Norway, more stem cracks were reported in fast-growing spruce proveniences than among slow growing ones [10]. The same pattern was observed in southern Sweden, where provenance mean DBH was correlated $(r=0.74)$ with the incidence of stem cracks, which varied from $1 \%$ for provenances with the smallest $\mathrm{DBH}$ to $\sim 10 \%$ for fast growing provenances 
with the largest mean DBH [13]. The provenance was also reported to have a significant effect on stem cracking in western Latvia [20].

Nevertheless, similar to a Swedish study [33], no significant difference in the frequency of stem cracking among provenances was observed. The provenance differences could be masked due to a high stand density, which might have a restricted radial growth potential for different provenances, thus reducing the expression of stem cracks. Moreover, in earlier studies, the variance among provenances was more pronounced due to long transfer distances and subsequent maladaptation $[10,13,20,32,34]$, while our study site consisted of local eastern Latvian seedlots.

Still, the variation within a provenance may sometimes be large, as among geographically distant origins [2]. For local southeast Latvian provenances, the incidence of stem cracks within a family was not related to the family mean DBH (Figure 1). Within one provenance, the families with no cracks, as well as the ones with a ca. $79 \%$ incidence of stem cracks, could be found (Figure 1).

The estimated individual tree heritability for stem cracking score was low, and only $8.8 \%$ of phenotypic variances in the trial could be explained by an additive genetic variance. An estimated $h^{2}$ for DBH was ca. two times higher. High (0.45-0.57) broad-sense heritability for internal cracking was reported in clonal trials [30]. Still, the estimated family mean heritability was higher and it showed that ca. $20 \%$ of the phenotypic variance of stem cracking could be controlled with selection, based on half-sib progeny tests.

Nevertheless, a complex analysis of different sites would provide a more reliable view, since heritabilities for productivity and quality traits may vary widely from low to high, depending on the site $[30,35,36]$.

\section{Tree-Ring Analysis}

Trees with stem cracks were reported to have wider annual rings with a small latewood proportion, which led to wood with a high proportion of earlywood and subsequent poor strength and low density due to thin cell walls and delayed lignification $[10,13]$. Earlier studies indicated a clear negative correlation between basic density and annual ring width, and a positive relationship between basic density and cell wall thickness $[12,32,37,38]$.

Thin-walled earlywood cells with low basic density are more susceptible to collapse, which might explain more frequent cracking of larger trees having a higher proportion of earlywood than thick-walled latewood, in which lower tangential stresses could be expected [39]. In this study, the proportion of latewood shows a negligible difference among groups of cracked and unaffected samples. However, earlywood, as well as latewood density, was by ca. $50 \mathrm{~kg} \mathrm{~m}^{-3}$ lower (Table 3) for samples with cracks compared to undamaged wood, indicating a lower mechanical resistance, which might have promoted the induction of cracks [12].

Lower density for cracked trees correspond to earlier findings, indicating the importance of selection for less susceptible wood with higher density than excluding the cracking itself [13]. Control of earlywood density in breeding programs is suggested [12], as it is reported to have moderate to high broad-sense heritability (0.33-0.51) [30]. In addition, for vegetative propagation, the selection of appropriate clones should take into account the tree predisposition to stem cracking.

\section{Conclusions}

Larger trees with reduced wood density parameters were more prone to stem cracking. Likely caused by climatic factors, the manifestation of cracking had rather weak genetic control, as shown by non-significant family and provenance effects, though family mean heritability indicated a potential for selection based on progeny tests to reduce the incidence of cracks. There was no evidence of reduced latewood proportion for affected trees, though the exclusion of genotypes, with reduced wood density during breeding activities, may help to avoid trees prone to stem cracking. 
Author Contributions: Conceptualization, Ā.J. and T.M.; Methodology and Validation, Ā.J. and T.M.; Data Collection, J.K. and P.Z.; Data Analysis, E.B. and P.Z.; Writing-Original Draft Preparation, P.Z. and Ā.J.; Writing-Review \& Editing, A.G., Â.J., T.M., and J.K.; Supervision, Ā.J.; Project Administration, A.G.

Funding: This research received no external funding.

Acknowledgments: This study was carried out as an ESF project, "Measures to increase resilience of Norway spruce forests against impact of climatic changes," (No. 1.1.1.2/VIAA/1/16/120) and as a JSC LVM project, "Forest management risks: prognosis and minimization."

Conflicts of Interest: The authors declare no conflict of interest.

\section{References}

1. Schelhaas, M.J.; Varis, S.; Schuck, A.; Nabuurs, G.J. EFISCEN Inventory Database, European Forest Institute, Joensuu, Finland. Available online: http://www.efi.int/portal/virtual_library/databases/efiscen (accessed on 7 August 2017).

2. Westin, J.; Haapanen, M. Norway spruce-Picea abies (L.) Karst. In Best Practice for Tree Breeding in Europe; Mullin, T.J., Lee, S.J., Eds.; Skogforsk: Uppsala, Sweden, 2013; pp. $29-47$.

3. Aarrestad, P.A.; Myking, T.; Stabbetorp, O.E.; Tollefsrud, M.M. Foreign Norway Spruce (Picea abies) Provenances in Norway and Effects on Biodiversity; Norsk institutt for naturforskning: Trondheim, Norway, 2014.

4. Dzerina, B.; Girdziusas, S.; Lazdina, D.; Lazdins, A.; Jansons, J.; Neimane, U.; Jansons, Â. Influence of spot mounding on height growth and tending of Norway spruce: Case study in Latvia. For. Stud. 2016, 65, 24-33. [CrossRef]

5. Neimane, U.; Katrevics, J.; Sisenis, L.; Purins, M.; Luguza, S.; Adamovics, A. Intra-annual dynamics of height growth of Norway spruce in Latvia. Agron. Res. 2016, 14, 853-861.

6. Haapanen, M.; Jansson, G.; Nielsen, U.B.; Steffenrem, A.; Stener, L.-G. The Status of Tree Breeding and Its Potential for Improving Biomass Production: A Review of Breeding Activities and Genetic Gains in Scandinavia and Finland; SkogForsk: Uppsala, Sweden, 2015.

7. Jansons, Ā.; Donis, J.; Danusevičius, D.; Baumanis, I. Differential analysis for next breeding cycle for Norway spruce in Latvia. Balt. For. 2015, 21, 285-297.

8. Lindner, M.; Maroschek, M.; Netherer, S.; Kremer, A.; Barbati, A.; Garcia-Gonzalo, J.; Seidl, R.; Delzon, S.; Corona, P.; Kolström, M.; et al. Climate change impacts, adaptive capacity, and vulnerability of European forest ecosystems. For. Ecol. Manag. 2010, 259, 698-709. [CrossRef]

9. Avotniece, Z.; Rodinov, V.; Lizuma, L.; Briede, A.; Klavinšs, M. Trends in the frequency of extreme climate events in Latvia. Balt. 2010, 23, 135-148.

10. Dietrichson, J.; Rognerud, P.A.; Haveraaen, O.; Skroppa, T. Stem cracks in Norway spruce (Picea abies (L.) Karst.). Rep. Nor. For. Res. Inst. 1985, 38, 1-32.

11. Caspari, C.O.; Sachsse, H. Cracking of Norway spruce. Forst Holz 1990, 45, 685-688. (In German)

12. Grabner, M.; Cherubini, P.; Rozenberg, P.; Hannrup, B. Summer drought and low earlywood density induce intra-annual radial cracks in conifers. Scand. J. For. Res. 2006, 21, 151-157. [CrossRef]

13. Persson, A. Stem cracks in Norway spruce in southern Scandinavia: Causes and consequences. Ann. For. Sci. 1994, 51, 315-327. [CrossRef]

14. Vasiliauskas, R.; Juška, E.; Stenlid, J.; Vasiliauskas, A. Clonal differences and relations between diameter growth, stem cracks and fungi in a 36-year-old clonal seed orchard of Norway spruce (Picea abies (L.) Karst.). Silvae Genet. 2001, 50, 227-233.

15. Arhipova, N.; Jansons, A.; Zaluma, A.; Gaitnieks, T.; Vasaitis, R. Bark stripping of Pinus contorta caused by moose and deer: Wounding patterns, discoloration of wood, and associated fungi. Can. J. For. Res. 2015, 45, 1434-1438. [CrossRef]

16. Burneviča, N.; Jansons, Ā.; Zaluma, A.; Klavina, D.; Jansons, J.; Gaitnieks, T. Fungi inhabiting bark stripping wounds made by large game on stems of Picea abies (L.) Karst. in Latvia. Balt. For. 2016, 22, $2-7$.

17. Baders, E.; Donis, J.; Snepsts, G.; Adamovics, A.; Jansons, A. Pruning effect on Norway spruce (Picea abies (L.) Karst.) growth and quality. For. Stud. 2017, 66, 33-48. [CrossRef]

18. Napola, J. The success of the origins of Eastern and Mid-European Norway spruce in southern Finland. Work. Pap. Finn. For. Res. 2014, 288, 77. (In Finnish) 
19. Napola, M.; Napola, J. Observations and results of stem damages in the experimental Norway spruce plantations. Work. Pap. Finn. For. Res. 2014, 296, 51. (In Finnish)

20. Zeltiňš, P.; Katrevičs, J.; Gailis, A.; Maaten, T.; Jansons, J.; Jansons, Ā. Stem cracks of Norway spruce (Picea abies (L.) Karst.) provenances in Western Latvia. For. Stud. 2016, 65, 57-63. [CrossRef]

21. Harris, I.; Jones, P.D.; Osborn, T.J.; Lister, D.H. Updated high-resolution grids of monthly climatic observations-The CRU TS3.10 Dataset. Int. J. Climatol. 2014, 34, 623-642. [CrossRef]

22. Spiecker, H.; Hansen, N.; Schinker, M.G. High-Frequency Densitometry-A New Method for the Rapid Evaluation of Wood Density Variations. IAWA J. 2003, 24, 231-239.

23. Gilmour, A.R.; Anderson, R.D.; Rae, A.L. The analysis of binomial data by a generalised linear mixed model. Biometrika 1985, 72, 593-599. [CrossRef]

24. Falconer, D.S.; Longman, T.F.C.M. Introduction to Quantitative Genetics, 4th ed.; Longman Group Ltd.: London, UK, 1996.

25. Christensen, R.H.B. Ordinal-Regression Models for Ordinal Data. R Package Version 2015.6-28. 2015. Available online: https://cran.r-project.org/web/packages/ordinal/ordinal.pdf (accessed on 21 February 2018).

26. Grissino-Mayer, H.D. Evaluating crossdating accuracy: A manual and tutorial for the computer program COFECHA. Tree-Ring Res. 2001, 57, 205-221.

27. Jansons, Ā.; Matisons, R.; Krišāns, O.; Džerina, B.; Zeps, M. Effect of initial fertilization on 34-year increment and wood properties of Norway spruce in Latvia. Silva Fenn. 2016, 50, 1346. [CrossRef]

28. R Core Team R: A Language and Environment for Statistical Computing 2016. Available online: http: / / www.R-project.org/. (accessed on 22 February 2018).

29. Persson, A. How genotype and silviculture interact in forming timber properties. Silva Fenn. 1994, 28, 275-282. [CrossRef]

30. Hannrup, B.; Cahalan, C.; Chantre, G.; Grabner, M.; Karlsson, B.; Le Bayon, I.; Jones, G.L.; Müller, U.; Pereira, H.; Rodrigues, J.C.; et al. Genetic Parameters of Growth and Wood Quality Traits in Picea abies. Scand. J. For. Res. 2004, 19, 14-29. [CrossRef]

31. Giertych, M. Genetics. In Biology and Ecology of Norway Spruce; Tjoelker, M.G., Boratyński, A., Bugała, W., Eds.; Springer: Dordrecht, The Netherlands, 2007; pp. 115-155.

32. Persson, B.; Persson, A. Variation in stem properties in a IUFRO 1964/1968 Picea abies provenance experiment in southern Sweden. Silvae Genet. 1997, 46, 94-101.

33. Eriksson, G.; Andersson, S.; Schelander, B. Lovande tillvaxt hos introducerade granprovenienser i en kombinerad klon-och froplantsplantage i norra Uppland. Sver Skogvardsforb Tidskr 1975, 3, 277-286.

34. Suvanto, S.; Nöjd, P.; Henttonen, H.M.; Beuker, E.; Mäkinen, H. Geographical patterns in the radial growth response of Norway spruce provenances to climatic variation. Agric. For. Meteorol. 2016, 222, 10-20. [CrossRef]

35. Haapanen, M. Impact of family-by-trial interaction on the utility of progeny testing methods for scots pine. Silvae Genet. 1996, 45, 130-135.

36. Haapanen, M.; Velling, P.; Annala, M.-L. Progeny trial estimates of genetic parameters for growth and quality traits in Scots pine. Silva Fenn. 1997, 31, 3-12. [CrossRef]

37. Molteberg, D.; Høibø, O. Development and variation of wood density, kraft pulp yield and fibre dimensions in young Norway spruce (Picea abies). Wood Sci. Technol. 2006, 40, 173-189. [CrossRef]

38. Irbe, I.; Sable, I.; Noldt, G.; Grinfelds, U.; Jansons, A.; Treimanis, A.; Koch, G. Wood and tracheid properties of Norway spruce (Picea abies [L.] Karst.) clones grown on former agricultural land in Latvia. Balt. For. 2015, $21,114-123$.

39. Mattheck, C. Wood-The internal optimization of trees. Arboric. J. 1995, 19, 97-110. [CrossRef]

(C) 2018 by the authors. Licensee MDPI, Basel, Switzerland. This article is an open access article distributed under the terms and conditions of the Creative Commons Attribution (CC BY) license (http:/ / creativecommons.org/licenses/by/4.0/). 